\title{
EMBODIMENT OF LOCAL WISDOM FOR ENVIRONMENTAL SUSTAINABILITY: PRACTICING ECO-THEOLOGY IN KAMPUNG NAGA
}

\author{
Ridho Afifuddin* \\ re77abrory@gmail.com
}

\begin{abstract}
Abstrak
Paper ini mencoba untuk menguraikan praktik masyarakat adat Kampung Naga dalam melestarikan lingkungan yang berlandaskan pada kearifan lokal disertai keyakinan agama yang melekat pada diri mereka. Metode pengambilan data dalam paper ini adalah participant observation dan studi etnografis secara mendalam. Dengan menggunakan pandangan dunia (world view) sebagai basis dasar cara pandang pengetahuan, penelitian ini menghasilkan beberapa poin penting. Pertama, bahwa masyarakat adat dengan pengetahuan lokalnya selalu berupaya untuk hidup damai dengan siapapun dan apapun yang ada di lingkungan sekitar mereka. Upaya untuk hidup damai ini bukan sekedar dimaknai sebagai sebuah tugas, namun lebih kepada way of life yang secara fundamental menjadi bagian yang tidak dapat dipisahkan dari kehidupan mereka. Lebih dari itu, kehidupan yang selaras dan damai bersama alam ini, sesungguhnya juga disadari sebagai bentuk pengejawantahan dari nilai-nilai spiritual. Spiritual masyarakat adat Kampung Naga merupakan bentuk kolaborasi cantik antara tuntunan adat dengan ajaran agama Islam. Oleh karena itu, ajaran Islam sebagai agama samawi mampu dihadirkan dalam wajah lokal ala Kampung Naga tanpa menghilangkan esensi dari nilai keislaman itu sendiri
\end{abstract}

Kata kunci: Ekoteologi, Masyarakat Lokal, Lingkungan, Kearifan Lokal

\section{Abstract}

This paper attempts to describe the practice of Kampung Naga indigenous peoples in preserving the environment based on local wisdom along with their inherent religious beliefs. Methods of data retrieval in this paper are participant observation and in-depth ethnographic studies. By using the world view as the basic basis of the worldview of knowledge, this study produces several important points. First, that indigenous peoples with their local knowledge always try to live peacefully with anyone and everything in their environment. Efforts to live peace is not just interpreted as a task, but rather the way of life that is fundamentally an integral part of their lives. Moreover, a harmonious and peaceful life with this realm is, in fact, also realized as a form of embodiment of spiritual values. Spiritual indigenous peoples Kampung Naga is a beautiful collaboration between traditional guidance and Islamic teachings. Therefore, the teachings of Islam as a divine religion can be presented in the local face of Kampung Naga without removing the essence of Islamic values itself

Key words: Eco-theology, Indigenous People, Environment, Local Wisdom

\section{INTRODUCTION}

The environment is an integral part of all human life because it is closely related to basic needs of individuals and community groups. This need is not only for the fulfillment of eating and living, but also the need for continuity of generations of all humanity. The living environment is closely related to natural resources, where nature with all its contents is the source of life for all living creatures on

* Dosen Jurusan Ushuluddin dan Ilmu Sosial STAIN Kediri the earth, either human or animals and plants. Ecologically, human beings are one of the subsystems in the environmental ecosystem. Thus, human beings cannot be separated from the environment. They become a single unit and form a functional relationship interrelated each other. ${ }^{1}$

Discussions about the environment are not really a new thing. We can find a variety

${ }^{1}$ Erwan Baharudin, Kearifan Lokal, Pengetahuan Lokal dan Degradasi Lingkungan (Jakarta: Universitas Esa Unggul, 2002), p. 2. 
of interesting topics related to this issue from a variety of fields, from academics, activists and government. Various programs were also carried out by the government to accompany even advocating the preservation of the environment. One thing that presumably can we draw provisional conclusions, that the environment is actually not a trivial issue, nor an issue for the government and activists, but this is a problem for all human beings living on the earth.

Human being with the ability of intelligence often regarded as the central figure (or least) the principal actors in the use of the earth as a place to stay. As the implications of this anthropocentric perspective, then attempted to take advantage of whatever is contained in the earth. The utilization depends on the needs of individuals and communities. As the development of the human civilization, their need for nature is also experiencing growth. From here, then the origins of environmental problems arise. Natural resources are limited dealing with human needs which are unlimited. The human need for nature, we can see clearly in the case of industrialist society.

In postmodern studies, discussing the impact of the industrialization of the natural environment is not a taboo anymore. We know that the industrialization characterized as a productive society in all aspects, and also characterized by the emergence of new progress in science relating to the industry. There are so many new job opportunities for many people. Along with the development of human civilization, finally appears assessment that the progress of a nation judged by how far the economy, education and development are progressed.

At this point, almost (maybe all) countries compete to develop its grandeur of each. The most unfortunate of the progress of the economy is the presence of massive exploitation of nature. The impact of this exploitation can be seen in various parts of the world, among which are the melting iceberg in the Atlantic Ocean, the unpredictable change of seasons and many other environmental damage cases. Most of these cases are caused by the human perspective that position themselves as subjects and other creatures as objects. This perspective ultimately leads to exploitative behavior on the environment. They assume that the universe was created by God (if they are religious) solely to satisfy human needs. In this case, Lynn White, a medieval historian, noted that religious anthropocentric perspective becoming one of the main causes of environmental destruction. ${ }^{2}$ It is true, it seems that nature was created to satisfy human needs, but we encountered the emergence of differences among the needs in their community.

In the discussion of human needs, I see a difference between industrialist societies characterized by modernization with traditional society characterized by antiquity. What I mean by traditional societies are the local communities (indigenous people). They are often regarded as second class citizens. The local communities are often also referred to as marginal people, more than that, they were regarded as uncivilized people. As the implications of the mainstream view on them, it brings up the efforts to change them to evolve towards modernity. Many of the programs promoted by the government to "progress" the lives of indigenous people considered less advanced, or even backward. In fact, if we look at this objectively, the lives of indigenous peoples are fulfilled by themselves without any interference from outsiders. Moreover, they are always able to be kind to the environment and nature. It is often the starting point of conflict between indigenous peoples and outsiders.

Persoon viewed Indonesia as a developing country, on the other hand, in the development of many indigenous people are increasingly marginalized. In Indonesia state policies, however, this distinction is looked upon in

${ }^{2}$ Audrey R. Chapman, Bumi yang Terdesak: Perspektif Ilmu dan Agama Mengenai Konsumsi, Populasi dan Keberlanjutan, (Mizan, Bandung: 2007), p. 152. 
different manner. It is not conceptualized in terms of indigenous. The government looks upon this groups as deviating from the cultural mainstream, and policies are aimed at bringing these people back into the mainstream of Indonesia life. ${ }^{3}$

Relating to the case of local community, Indonesia ignored the UN Year of Indigenous peoples. The government refrained from participating in international discussions on the topic, insisting that the indigenous issues does not apply to Indonesia. Indonesia, it claimed, is considered to be a nation consisting predominantly of indigenous population (permanent mission 1993). Even so, numerous international organizations invited representatives of Indonesian indigenous peoples to speak about the situation in their country. Recently, the Asian Development Bank involved some members of indigenous groups in Indonesia to join discussions about operational procedures for development projects affecting indigenous peoples in Asia. Due to increased awareness and a higher degree of organization, some of these groups present themselves as separate ethnic groups or indigenous peoples and speak out more vocally than they have in the past. ${ }^{4}$

Relating to the environment, the attitude of indigenous communities in preserving nature is based on the beliefs they have been embedded in adat rules that inherited from their ancestors. Adat rules in society have existed since prehistoric times until today. The rule is the positive behavior of human being in touch with nature and the surrounding environment that can be sourced from religious values, culture, ancestor's advice or local culture. ${ }^{5}$ Indigenous peoples see themselves as part of nature. Humans, animals, plants and even other

${ }^{3}$ Gerard Persoon, "Isolated Groups or Indigenous peoples: Indonesia and the International Discourse," in Globalization, Localization and Indonesia (Netherland: KITLV, Royal Netherlands Institute of Southeast Asian and Caribbean Studies, 1998), pp. 281-304.

${ }^{4}$ Persoon, “Isolated Groups or Indigenous Peoples.," pp. 281-304.

${ }^{5}$ Baharuddin, 2012. Kearifan Lokal, Pengetahuan Lokal., p. 106. objects have equal position. Cosmological, Hallowell mention human relationship with nature in indigenous communities as intersubjective cosmos relationship, i.e. the relationship between the subjects by subjects. Hallowell (1975) introduced the paradigm of interpersonal relationships. The paradigm asserts that human beings perceive the forms of non-human as "associates" or partner in shaping their social environment. ${ }^{6}$ The way in which indigenous peoples have led to an attitude is always trying to maintain good relations between people and their environment.

The attitude of environmental conservation undertaken by indigenous peoples in fact is not without basis. Every indigenous people have life guidelines of each, guidelines for life in general we can understand it as a local wisdom. Their wisdom shaped by faith in the mythology that led to certain behavior. Thus, the attitude of preservation of the environment carried out by them is part of the manifestation of the local wisdom that they held so as to create a beautiful environment and away from pollution and exploitation. Depart from the above case of indigenous peoples, in this paper I will discuss about one of the indigenous community, which preserves their environment as well. I have been doing research in indigenous communities located in Kampung Naga Tasikmalaya, West Java. Kampung Naga society is one of the indigenous peoples who still adhere to the old way of life today.

They live not far from other villages. This provides the opportunity for people outside to be in direct contact with them. Many of the academic and government circles visit Kampung Naga. Moreover, Kampung Naga has even become one of the locations recommended by the government Tasikmalaya to be visited by tourists, both from local to foreign tourist. Kampung Naga is considered unique and

${ }^{6}$ Samsul Maarif, "Indigenous Religion of Ammatoa of Sulawesi, Indonesia: Ethical Ways of Relationship among Persons of Different Beings," article presented at $5^{\text {th }}$ SSEASR Conference, Manila, Philippines, 16-19 May 2013. 
interesting because of their lifestyle from the first until now is still the same. They live in a village located in a valley called Nagawir. Their houses made of wooden planks, and their roofs made of palm leaves that tens or even hundreds of years old. Kampung Naga society rejects the electricity into their village. This is done because it has become their duty to keep the tradition they had inherited from their ancestors. In addition, many adat rites were often held for the preservation of life guidance of the ancestors. One of them is the obligation of life guidance to be simple life. This simple life, is done by the use of natural resources appropriately, do not seek or collect in excess. For them, human life on earth should be aware that they are living with nature and not living in nature only. Of this guidance, there appears a friendly attitude towards the environment. The establishment of a harmonious society cannot be maintained without re-envisioning the sacred in nature as well as in culture. Based on the premise that environmental degradation is not a resource problem but an attitude problem, it is important to return the innate wisdom that informs us of our primordial harmony with the natural world. This primordial harmony is at the heart of several religious traditions. ${ }^{7}$

\section{THE COSMOLOGY OF KAMPUNG NAGA}

In this paper, I think it is important to discuss cosmology of Kampung Naga society. By looking at their cosmology, we can probe further about their worldview so that it raised the relationship between the physical reality that exists today and the values contained in it. So, we can find the relation between life guidance (worldview) that is sacred to the profane world that has been applied in everyday life. Cosmology of Kampung Naga is divided into three parts, the upper, middle and lower. An upper place is the residence of the death ancestors, a gathering place for people who are sacred (karuhun). The middle

${ }^{7}$ Bahar Davary, "Islam and Ecology: Southeast Asia, Adat, and the Essence of Keramat," in ASIANetwork Exchange, Fall 2012, Vol.20/1., p. 13. is the place of human habitation, symbolizes regularity and cleanliness. The lower place is the space as a center of the chaos, the home of the devil. Physically, the concept of these three spaces, we can see from the concept of spatial village.

Kampung Naga divides the territory into three parts. The first is a sacred area that is in upper area. They call it a sacred forest. In this forest, there are ancestors' graves. Not everyone can get into this area, because only the Sanaga descendants are entitled. This area represents the pinnacle of the cosmos, which has the highest value of the other places. The most valuable aspect of the sacred forest is due to the tombs of the ancestors. Coupled with the sacred forests, there is Bumi Ageung that serves as a repository of most valuable treasure in Kampung Naga. Here is a storage heirlooms area and ancestral heritage. It is also the center of Kampung Naga cosmology.

For the people of Kampung Naga ancestors is central for everything. The ancestral spirits of the most important, from the standpoint of the villagers is a forerunner. The human spirit which was first clean (mbabad) of forest and founded the village. People like this are often referred as a noble person or someone who has a strong religious belief. ${ }^{8}$ Ancestor has a great influence, even the center of everything, as well as the lifestyle that they hold to this day that their existence is a form of continuation of the tradition of them.

For Kampung Naga ancestors are parents. As in most cases, parents are the place where a child resting his life, a place to shelter and complain. The way that the ancestor thought to be associated with their offspring, reflects the relationship between parents and children. The role of parents, especially mothers, should ideally provide care and concern. So, where children are gradually taught to become a member of the adat (Sunda) and they are also

${ }^{8}$ Robert Wessing, "A Community of Spirits: People, Ancestors, and Nature Spirits in Crossroads," in An Interdisciplinary Journal of Southeast Asian Studies, Vol. 18, No. 1. pp. 11-111. 
protected from "the dangers and distractions of life. ${ }^{9}$

As a consequence of the highest of the cosmos, sacred forests get different treatment from other places. One of the attitudes shown is the entire community banned confronts the foot, also defecate or urinate towards the west. This was done asides tombs of the ancestors are in the west village, west side is also the direction of Qiblah, as Islam in a position in Indonesia worship heading to the west. This behavior is the part of guidance of a character which is kept to be embedded and run in daily life. From this behavior, we can view relationship between adat guidance to the teachings of Islam they believe. They combine Islamic teaching and adat in a beautiful way. The two are not contradictory, even creating a mutually beautify behavior between Islam and local culture.

The second area of Kampung Naga cosmology is the middle place, namely residential areas. This area is home to the human beings that consist of several houses, mosque, pasholatan, Bale Patemon, granary and a few other places. This area is surrounded by a moat and fish pond that flows into rivers which are in the bottom area. They divide the space into two, namely a clean and a dirty place. Inside the clean room are housing, mosque, Bale Ageung, Bale Patemon, granary. The dirty room is the space where the dirt removed outside the fence. This space is located outside the residential area. dirty place include shower / toilet, pool, stables goats and sheep, a pound of rice, and trash. A dirty room is outside of the clean room where the water flowed from huluwotan into the river. Around the middle of the settlement, the entire building in it is made on the basis of the benefit principle. Almost all of each has a meaning. The space management has not been changed from the first until now. Everyone who lives in this area is obliged to follow the lifestyle as well as lifestyle of

${ }^{9}$ Hildred Geertz, The Javanese Family. A Study of Kinship and Socialization, (New York: The Free Press of Glencoe, 1961), pp. 105-107.
Kampung Naga society. All obligations must be fulfilled and any ban should be shunned.

Housing in Kampung Naga established facing south and north. The significance of facing the south and the north is that every human being always sees both sides of life. South is the direction towards the sea, symbolizing the worldly life, while the north is the direction of the mountain, symbolizing the life hereafter. The house is built with materials found in the forest. From an ecological perspective, the practice of making a house like this, is capable of preserving a sustainable of environment. Utilization of agricultural products only the necessary and not excessive is one implication of the value of local wisdom in synergy with ecosystem sustainability. Likewise, the arrangement structure is not changed.

Changing in housing structures can disrupt the order that has been built by the ancestors, and this will lead to a bias towards lifestyle. In addition, it will also change the order of the various rituals that prevailed in Kampung Naga and this means that should fade mandate from ancestors to kept its authenticity. Thus, by returning to local wisdom, at least motivate people to respect for other beings (nonhumans). Respect human to non-human that can restrict the natural human tendency to exploit nature excessively. Determination of the shape and material of housing, reflecting their relationship with the ancestors. Even the attitude of preservation of the environment is not free of the believe of citizens in the reciprocal relationship between humans and nature, including non-human beings.

The third is the lowest area. This area is forbidden forest. This forest is located in the east village and bordered by a large river. Kampung Naga societies believe that the forest is the home of the evil spirits. This forest is the center of the chaos, the center of darkness. So, everyone is prohibited to enter into this forest. Everyone who has an interest to take something from this forest, usually to get the plants as medicines, is only allowed to step on 
one leg, while the other leg is outside the forest area. The prohibition is in fact not only for residents of Kampung Naga, but also the whole person. Kampung Naga society believe that if someone took the branches of the tree then he will get a disaster. Actually, the function of forest preservation in Kampung Naga does not differ much with the function and purpose of forest conservation at large, such as a water source, but looking at the context of the Naga society, it may have other functions such as to prevent landslides, environmental conditioning and protective of the big wind. Therefore, the people are prohibited to manage and touched the forest because it could result in the destruction of forests.

\section{LOCAL WISDOM FOR ENVIRONMENT}

The idea of environmental conservation in Kampung Naga is indeed not the purpose of the practice of local wisdom. Protecting the environment is just one of several implications and benefits of the attitude of the embodiment of the values thereof. That is, a good attitude for the noble values of local wisdom, able to create an ecosystem that is also good for the environment. There are some practices of local wisdom performed by Kampung Naga that is closely related to the ecological implications. Here, we will expound on these practices and we will describe its implications relating to the environmental preservation.

The first is a system of agriculture. Components of agricultural system in Kampung Naga include rice fields, farms and forests. The three agricultural areas are cultivated through traditional methods, neither fields, gardens nor do forests use modern equipment. The practice of processing these fields, we can understand it from the way Traditional Ecological Knowledge. This term has emerged as a reaction to industrialist public views that tend to see the environment as an object. This Subject-object way of see, is also based on the view that nature was quite separate with human being. The result of it is the treatment of overexploitation. ${ }^{10}$ In contrast to the way in which indigenous peoples, in this case Kampung Naga, they see themselves as people who live with nature. This worldview is able to create a harmony relationship with nature. Pierotti and Wildcat assume that humans will always be connected to the natural world and there is no separation between nature and human beings, as well as their activities. ${ }^{11}$

The inseparable between human and nature, in fact constituted by Kampung Naga view that human being and all life practices (including farming) is inseparable with the Supernatural One. Hallowell mention it as other than human being. That view, we can also understand it as part of the representation of the value of religion (faith/believe) adopted by Kampung Naga. As a consequence of that belief, then Kampung Naga see rice, not only as a vegetable, but more than that. In this section, we will discuss how rice has a special position in the community of Kampung Naga. Their treatment of rice, we can see from the way they plant, care until the harvest method.

Kampung Naga society likens rice as mothers or wives who bear children, this attitude is stated in terms of Sunda netek teraje nicak kemalan. So, they have to treat rice as they would treat a pregnant woman. Respect for the rice, is done through certain rituals and done during the process of early planting, mid, time of harvest until the mashing process. The purpose of this is that the rice produced by the blessing of God. Respect and mutual relations are central values that regulate relations found in the rituals of society, between the human and supernatural spirits. ${ }^{12}$

Rice has completed pounded then set aside some for storage in village granaries. This granary is a food resilience system that is set

${ }^{10}$ Raymond Pierotti and Daniel Wildcat, "Traditional Ecological Knowledge: The Third Alternative," in Ecological Applications, Vol. 10, No. 5. 2000, pp. 1333-1340.

${ }^{11}$ Pierotti, "Traditional Ecological Knowledge," pp. 13331340.

${ }^{12}$ Cynthia T. Fowler, "The Ecological Implications of Ancestral Religion and Reciprocal Exchange in a Sacred Forest in Karendi (Sumba, Indonesia)," in Worldviews 7, No 5, 2003, pp. 303-329. 
to support farmers who failed to harvest. If the harvest is insufficient for the necessities of life, so they agreed to take the rice savings. Agricultural systems positioned the plant as an integral part of human life, as rice described as wives or mothers to bear children, taken care of and treated very well. In Javanese culture, rice is often referred as mbok Sri. She is the protagonist figure in Javanese myth that keeping rice, also commonly referred to the Goddess of rice. ${ }^{13}$ In some areas, especially in the eastern Indonesia, Dewi Sri is also often referred as a symbol of fertility.

In addition to the treatment of rice, Naga forests also applied in accordance with their respective functions without destroying the existing ecosystem. The treatment community for the environment rooted to the local wisdom centered on a projection of obedience to ancestors to create a harmony life with nature.

The second is a system of believe. For many local communities (indigenous people) ethical behavior based on the life guidance or adat law. Many life guidance contained in the local wisdom came after years by listening and retelling the stories of the world. Human being has a feeling built on the old story, that in this world all of which are filled with creatures that have relevance to humans. The old stories about the world, able to influence the human mind to do something on the basis of trust, even this is done communally. The old story about the world can be understood as mythology. Myth built in Kampung Naga actually has its own purposes. Each myth explains how a goal is achieved by certain means. ${ }^{14}$ Although not infrequently, beliefs that have been held by indigenous peoples over the years, came under pressure from both inside and outside the group. For the people of Kampung Naga, the human relationship with nature is kinship, in the sense of the relationship between fellow

\footnotetext{
${ }^{13}$ Rens Heringa, "Dewi Sri in Village Garb: Fertility, Miyth and Ritual in Northeast Java," in Asian Folklore Studies, 1997, pp. 355-377.

${ }^{14}$ Claude Levi-Strauss, Mitos, Dukun dan Sihir, Jakarta, Kanisius, 1997), pp. 125.
}

creatures of God. The relationship is based on a sense of oneness with nature.

Philosophy of life with nature become the basic foundation of their lives co-exist with nature. This ecological character, we can see by the name given by Enrique Salmon as "Kincentric Ecology". ${ }^{15} \mathrm{He}$ explained that in order to live in nature, human can survive only if he saw anything around him as kin. Equal involvement among them is the principal choice to survive.

As in Kampung Naga, human perception of the world is built on the basis of bond-centered and attached to the ancestors. Ancestors become a key principal for the people of Kampung Naga in identifying themselves. In this context, their perceptions arose not from themselves, but are projected guidance held and applied in everyday behavior communally. From what they had inherited from the ancestors, it form a system of beliefs, social and cultural rights that reflect a friendly attitude toward nature.

As indigenous people who are committed to maintaining the tradition, they have belief system contained in some of Sunda terms, namely papagon and pamali. Papagon is the teachings from ancestors who are commands or teachings must be executed. In its delivery, papagon is pitutur. This is traditional values comes from the ancestors conveyed through orally from generation to generation. It is part of forms of education from the elders to their children through storytelling culture and advice. In understanding papagon, we can refer to what is defined by Vansina as an oral tradition. Jan. Vansina defines oral tradition as witness orally transmitted from one generation to the next. He also explained that the oral tradition is what one has learned from the story hearsay or verbal testimony which tells an event, rather than on what he had witnessed and remembered. ${ }^{16}$

${ }^{15}$ Enrique Salmon, "Kincentric Ecology: Indigenous Perceptions of the Human-Nature Relationship," in Ecological Applications, Vol. 10, No. 5, 2000, pp. 1327-1333.

${ }^{16} \mathrm{Jan}$ Vansina, "Once upon a Time: Oral Traditions as History in Africa," in Daedalus, Vol. 100, No. 2, The Historian 
David William Cohen argues that the oral tradition or knowledge of the past is subject to involvement in the arrangement of social activities. ${ }^{17}$ Thus pitutur from generation to generation continues to this day. This pitutur (papagon), also influenced by socio-cultural system which is taking place within indigenous communities. Oral tradition consisted from testimony transmitted through generations. It has undergone a transformation due to the involvement inherent in the practice of sociohistorical and dialectical interaction between the collective knowledge and pragmatic interests of the individual.

Departing from it, we can understand that the stories and advices from the ancestors are construction of the history that made up beliefs of indigenous peoples. Until today, the value or the teachings from the past is always transformed in accordance with the interests and needs of the community without reducing the essence.

Pamali is a form of doctrine to leave something, both are actions or words. Pamali also called as taboo, are also very close to the myth originating from a given set of stories from generation to generation orally. Pamali word is always embedded in the hearts and minds so that be the guardian in said words and behavior.

Van Gennep argues that taboo is an expression of the social obligation and thus create social sustainability. Taboo serves to legitimize the possession of spirits in a similar way in which they organize descent/ grandchildren. Taboo is prohibitions that depend on enforcement law or fear, in which it is a mixture of a fear, self-loathing, unknown fear, disgust, and perhaps also other factors. ${ }^{18}$ As the prevailing pamali, Kampung Naga society believes without curiosity of what they believe.

and the World of the Twentieth Century, MIT PRESS, 1971. pp. 444.

${ }^{17}$ David William Cohen, "The Undefining of Oral Tradition," in Ethnohistory, Vol 36, No 1, 1989. Duke University Press, pp. 11.

${ }^{18}$ E.F. O'Doherty, “Taboo, Ritual and Religion,” in Studies: An Irish Quarterly Review, Vol. 49, No. 194, 1960, pp. 131-143.
In this pamali believe, no explanation of why it is prohibited and no attempt to seek the intent of the ban. The main basic prohibition in life as Kampung Naga society stated in one Sunda sentence; Nanak ban ngadu, ngamadaat, ngawadon. Pit, drunk (position, possessions, drinks, etc) and play women (adultery). So, the sentence is the subject of restrictions that cannot be tampered and applicable to all members of Kampung Naga society.

In the implementation of these taboos, there is no written prohibition, as well as cutting down trees, prohibited from disposing of garbage or the other. Despite all the restrictions derived from verbal but they are very familiar with what is permitted and what not to do. Because of this already embedded in depth ranging from childhood to adulthood and hereditary. Pamali in action is a behavior that should be avoided to do something. For example, behavioral taboos are actions that should not sweep in the afternoons and evenings. As an example for pamali in word is should not talk about the ancestors on Tuesday, Wednesday and Saturday. They call it "pego and taboos about the origin of the village". In addition, people also assume a habit that is not derived from the teachings of their ancestors. It is also considered taboo. So, for a lifestyle that is currently undertaken will not be changed because it is also part of pamali "bisi pamali kumaonam" pamali to worry if anything will be happened.

Through these taboos, Kampung Naga has control over people's behavior regarding environmental ecosystem. As pamali take a fish with poison and pollute rivers with soap. Building a house using industry materials is also taboos, except nails. So, roofs made of palm fiber and the walls were made of woven bamboo. The entire stanchion use wooden beams. Local materials are tried to be fulfilled by them without damaging their forest. Nowadays, not all the building materials come from forests of Kampung Naga, but they buy from outside the village. It caused of the trees that can be used to build houses has been 
difficult to obtain if they rely from the forests around. The most important for them is the material and shape of the building, which is still in accordance with the provisions of adat.

As a result of pamali, if still done it will be considered as violation of adat guidance. This will bring harm to the perpetrator, also can harm others even all citizens Sanaga. If there is one of the adat members who violate these rules then he should be punished in accordance with the levels of violations. Violation of the rules is a form of action that has disrupted the balance. So, if the offender has made a mistake then he must return in accordance with the balance that has been disturbed. For example, the theft, the offender must return the money according to the amount of money was taken. It can also take the form of a ceremony should be done. The elders determine the execution by consensus.

\section{ECOLOGY BASED THEOLOGY}

A society that is sustainable in time and space has formed a pattern of life. The intangible cultural patterns undergo the process of inheritance of cultural and social values from all generation. Although on the one hand also undergone a transformation, the dynamics of life influence on environmental management. However, the Naga society still has a cultural pattern that has been sustained. ${ }^{19}$ This pattern can be discerned from their efforts to implement the rules of adat law. Almost all of cultural rules or guidance they hold until today is the legacy from ancestors of Kampung Naga.

In the practice of environmental management, Kampung Naga society uses local knowledge as principal instrument. The instrument applied in its distinctive shape. The theme of traditional ecological knowledge is important in the consideration of a broad range of questions related to nature-human

${ }^{19}$ Ridho Afifudin, Wacana Ecotourism, Antara Tuntunan dan Tontonan: Studi Kasus Masyarakat Adat Kampung Naga, Program Studi Agama dan Lintas Budaya, Sekolah Pascasarjana UGM Yogyakarta, 2014, p. 28 relationships. ${ }^{20}$ Kampung Naga's perceptions and knowledge are in part shaped by their values, worldviews, environmental ethics, and religion. In the exploration of environmental ethics and religion to an ecologically sustainable society, Kampung Naga and traditional ecological knowledge have attracted considerable attention from both scholars and popular society. Traditional ecological knowledge includes worldview and religious traditions of a society. Kampung Naga shares a range of environmental values and ethics along with their practices.

To understand the traditional ecological knowledge of Kampung Naga, we can see from the guidance of life they hold. Life guidance is the foundation of all behavior and ethics. So, the ethics on the environment is also based on the life guidance. Life guidance in Naga society are wasiat, amanat and akibat (testament, mandate and effect.). This culture reflects the nature of human beings as a creature of God, social beings, and creatures which are part of the universe. This world view is able to anticipate the future of life by living in harmony with the environment.

Testament is a heritage that could be a message that must be obeyed by all the residents of Kampung Naga. This testament covers about houses, farms, heirloom, and forests. A home for them has a social function, spiritual function, and the function of philosophy. Settlement patterns follow the contours of the type of traditional houses on stilts and the material is natural. This is an adaptation to the natural conditions. This is an attempt, management and use of the environment to obtain and maintain harmony with the environment carrying capacity. Knowledge of environmental sustainability shows new environmental paradigm, that care and impartiality environment, love nature, believe in limits to growth, convinced that the human part of the ecosystem, and realize

${ }^{20}$ Ashish Anthwal, Nutan Gupta, Archana Sharma, Smriti Anthwal, "Conserving Biodiversity through Traditional Beliefs in Sacred Groves in Uttarakhand Himalaya, India," in Resource, Conservation \& Recycling 54, Elsevier, 2010, p. 962. 
the interdependence between human and nature. The reality shows that the natural environment in Kampung Naga sustainable by the characteristics:

1. The ecosystem functions of natural resources continues to this day in sustaining the life of the community;

2. The controlled impact of pollutants (air, soil, and water);

3. The quality and quantity of resources nature is maintained.

Budaya wasiat that set the forest as the forbidden forest is the realization of the concept of protected forests and nature reserves, as a form of environmental ethics rooted in the local wisdom. Simplicity of society, is not identical to poverty could encourage erosion of belief in the sanctity of forest. They have an attitude of self-regulating and responding to the environment based on environmental arrangement relations. The natural environment is seen as an object that can provide good and bad reactions depend on human treatment.

Budaya amanat is the mandate/assignment for a simple and peaceful life, and ritual. simple and peaceful living culture have formed an independent community and treats the environment wisely. There's a saying teu saba, teu boga, teu banda teu boga, teu weduk teu bedas, teu gagah teu pinter and amanat ti kolot sacekap cekapna sakieu wae. This expression reflects a life that is unpretentious, does not show intelligence and assets held, and are not compelled to exploit natural resources.

It aims to maintain the harmony of life between citizens and maintain harmony with environment. They looked at the essence of the life is a message that human life has ties to nature as a source of life, so that the mandate will be retained because it has to work to maintain their existence in the natural environment and social environment of Kampung Naga.

Budaya amanat for ritual, generally, there are eight kinds of ceremonies always performed by them. The ritual closely related to environmental sustainability is a ceremony to build the house and farming. Build houses and plant rice starts and ends by ceremony as the expression of care and management in maintaining environmental compatibility. Every step of rites are follow a pattern that does not cause problems in life.

The principle of environmental conservation carried out community based sustainable environmental ethics. Environment as a resource has its limitations. Ceremony to build the house and farm are utilizing effort for environment and maintain its sustainability through cultural considerations, physical and biological adaptation. Activities and community treatment of the environment to achieve harmony of life with the natural environment, they become part of it and the nature become a source of livelihood. Rice cultivation without artificial fertilizers and pesticides does not mean they do not know, but it does with the environmental considerations that are not polluted.

Budaya akibat is a moral consequence for every culture offenders. Although no real sanctions, but feelings of guilt towards the ancestors will be punishment. Budaya akibat as a result has become part of the personality of the community as a form of socialization and enculturation success in the process of cultural inheritance or tradition. The younger generation as heirs of tradition already has the values of environmental ethics instinctively loves nature. Taking active part in preserving environment is realized by moral and spiritual responsibility as part of the obligations of their life.

Budaya akibat shows that the society is a society that already has a high natural knowledge. They view the natural environment as an example and mirror of life by obeying the rules and laws of nature. Moreover, a culture has a high spiritual value, which is equal to religious prohibitions. Although sanctions are only a sin but it is perceived by the perpetrator as an inner torment burden, regardless of whether the offense is known by others or not. 
The belief system in Kampung Naga, besides constructed on the basis of local knowledge, is also influenced by Islam. Islam as a religion set people ethics to worship. So, it is more related to the vertical relationship between human beings and God. However, the collaboration between religion and culture, we can see in the various actions that reflect Islamic values coupled with local culture beautifully.

All Islamic schools of law have set out guidelines for the proper treatment of animals and plants as well as natural resources. A simple example can be found in the edict that polluting the water is a sin according to the shari'ah. Other broad concepts such as justice adl kindness ihsan, and balance mizan are important points to be considered in the discourse on Islam and conservation, sustainable development, and resource management. The Qur'an prohibits wastefulness. In fact, wastefulness is synonymous with ungratefulness, and the term used for ungratefulness in most Muslim's languages has been $k u f r$, i.e. disbelief..$^{21}$ Religion is important as a main principle coupled with local knowledge. Both are never in contradictory in relation to environmental conservation.

Religious beliefs and rituals (invariable parts of the cultural milieu) are very much inter-linked and intimately related to the management of ecosystems. Religion aids the conservation of natural biodiversity in several different ways. The first is by providing ethical and social models for living respectfully with nature. For most cultures, religion is a primary means of judging right and wrong. Despite certain differences, nature is included in the religious code of morality and etiquette in all religions. These ethical beliefs and religious values influence our behavior toward others, including our relationship with all creatures and plant life. ${ }^{22}$

\footnotetext{
${ }^{21}$ Bahar Davary, "Islam and Ecology," pp. 15-16.

${ }^{22}$ Ashish Anthwal, "Conserving Biodiversity.," p. 962.
}

\section{CONCLUSION}

Society behaviors in Kampung Naga have its own rules that is based on moral and ethical tradition. Moral education is the basis for the act and interact. Moral for Kampung Naga is a character that shows a good attitude towards others. They will determine how the attitude that should be done depends on whom they interact. In general, moral based on the behavior is divided into several parts, i.e. morals toward God, human beings and the nature. A moral towards God is a vertical relationship and more individual. For them there is no pressure, as long as not to disrupt public interests.

Morals against fellow human beings are a form of social relations. This is regulated by the teachings of the ancestors through traditional norms. A moral towards nature is a human relationship with nature. How people look and position to the nature in accordance with the guidance of the local communities. As in Traditional Ecological Knowledge which includes religion and science, in the sense that religion is a ritual representation of community. Even, as a means to give moral sanction and code of ethics. All three forms of these relationships, we can understand it from the discussion about the construction of cosmology and spatial forms in Kampung Naga.

Cosmology is shaped by the experiences of ancient ancestors. The experience gained from long observation of the situation and natural conditions. Long interaction with nature, and build a construct of thought contained in various philosophy of life. Philosophy then believed to be the guidelines which should be done as a form of obedience. Philosophy coupled with the teachings of Islam who had been with the early ancestors. Anyone who does not obey the teachings of the ancestors, it is represented as someone who is unethical because it will cause damage.

From here, we can understand, that the beliefs of indigenous communities with local knowledge, able to synergize with the teachings of Islam well. Thus, matters relating 
to the behavior of environmental preservation, also based on the awareness of the value of the locality and theological aspects inherent in human beings.[]

\section{BIBLIOGRAPHY}

Anthwal, Ashish. Nutan Gupta, Archana Sharma, Smriti Anthwal, "Conserving biodiversity through traditional beliefs in sacred groves in Uttarakhand Himalaya, India," Resource, Concervation \& Recycling 54, Elsevier: 2010.

Afifudin, Ridho, Wacana Ecotourism, Antara Tuntunan dan Tontonan; Studi Kasus Masyarakat Adat Kampung Naga, Program Studi Agama dan Lintas Budaya, Sekolah Pascasarjana UGM. Yogyakarta, 2014.

Baharuddin, Erwan, Kearifan Lokal, Pengetahuan Lokal dan Degradasi Lingkungan, Jakarta: Universitas Esa Unggul, Friday Edition, 0810-2012.

Cohen, David William, “The Undefining of Oral Tradition," Etnohistory, Vol 36, No 1. 1989.

Chapman, Audrey R., Bumi yang Terdesak: PerspektifIlmu dan Agama Mengenai Konsumsi, Populasi dan Keberlanjutan, Bandung: Mizan, 2007.

Davary, Bahar, "Islam and Ecology: Southeast Asia, Adat, and the Essence of Keramat," ASIANetwork Exchange, Fall 2012, Vol.20/1.

Fowler, Cynthia T. "The Ecological Implications of Ancestral Religion and Reciprocal Exchange in a Sacred Forest in Karendi (Sumba, Indonesia)," Worldviews 7,3, 2003.

Geertz, Hildred, The Javanese Family. A Study of Kinship and Socialization, New York: The Free Press of Glencoe, 1961.

Heringa, Rens, "Dewi Sri in Village Garb: Fertility, Miyth and Ritual in Northeast Java," Asian Folklore Studies, 1997.
Levi-Strauss, Claude, Mitos, Dukun dan Sihir, Jakarta: Kanisius: 1997.

Maarif, Samsul, "Indigenous Religion of Ammatoa of Sulawesi, Indonesia: Ethical Ways of Relationship among Persons of Different Beings," $5^{\text {th }}$ SSEASR Conference, Manila, Philippines, 16-19 May 2013

O'Doherty, E. F. Taboo, Ritual and Religion. Studies: An Irish Quarterly Review,Vol. 49, No. 194, 1960.

Persoon, Gerard, Isolated Groups or Indigenous peoples: Indonesia and the International Discourse, Bijdragen tot de Taal-, Land- en Volkenkunde, Vol.154, No. 2, Globalization, Localization and Indonesia (1998). Published by: KITLV, Royal Netherlands Institute of Southeast Asian and Caribbean Studies.

Pierotti, Raymond, and Wildcat, Daniel, "Traditional Ecological Knowledge: The Third Alternative," in Ecological Applications, Vol. 10, No. 5, 2000.

Salmon, Enrique, "Kincentric Ecology: Indigenous Perceptions of the HumanNature Relationship,"Ecological Applications, Vol. 10, No. 5, 2000.

Vansina,Jan,"Once upon a Time:Oral Traditions as History in Africa," in Daedalus, Vol. 100, No. 2, The Historian and the World of the Twentieth Century, MIT PRESS, p. 1971.

Wessing, Robert, "A Community of Spirits: People, Ancestors, and Nature Spirits in Crossroads," An Interdisciplinary Journal of Southeast Asian Studies, Vol. 18, No. 1, 2006. 